\title{
PENGEMBANGAN MINUMAN INSTAN COKELAT- KEDELAI SEBAGAI MINUMAN KESEHATAN
}

\author{
Development of baverage chocolate-soybean instant as a health drink
}

\author{
Rosniati \\ Balai Besar Industri Hasil Perkebunan \\ Jl. Prof. Dr. Abdurahman Basalamah No. 28 Makassar \\ Pos-el: rosniati.kasim8@yahoo.com \\ (Artikel diterima 22 April 2016; direvisi 23 Mei 2016; disetujui 18 Juni 2016)
}

\begin{abstract}
The aim of this study was to develop the instant chocolate-soybean beverage as a health drink formulated from fermented and non-fermented cocoa powder, sucrose, and soymilk powder (creamer). The research methodology uses experimental methods and analysis. Process of instant chocolate-soybean beverage making refers to the process of Instant Chocolate-Ginger (Rosniati, 2011). The research uses four formulas based on material compositions i.e. formula 1 (sucrose $55 \%$, cocoa powder from fermented beans, and creamer 15\%), formula 2 (sucrose $55 \%$, cocoa powder from fermented beans $30 \%$, and soymilk powder $15 \%$ ), formula 3 (sucrose 55\%, cocoa powder from non-fermented beans $30 \%$, and creamer $15 \%$ ), formula 4 (sucrose $55 \%$, cocoa beans from non-fermented beans $30 \%$, and soymilk powder $15 \%$ ). The result shows that the formula of sucrose $55 \%$, cocoa powder from non-fermented beans $30 \%$, and soymilk $15 \%$ is the best product containing $11.25 \%$ polyphenol, 8.35 fat, $45.88 \%$ total sugar, 4.17 essential amino acid, 4.77\% non-essential amino acid, 45.12 unsaturated fatty acid, and 26.42 saturated fatty acid.
\end{abstract}

Keywords: baverage chocolate-soybean instant, cocoa powder, and soymilk powder

\begin{abstract}
Abstrak: Tujuan dari penelitian ini adalah untuk mengembangkan minuman instan cokelat- kedelai sebagai minuman kesehatan yang diformulasi dari kakao bubuk yang diolah dari biji fermentasi dan nonfermentasi, sukrosa, dan susu kedelai bubuk (atau krimmer). Metodologi penelitian menggunakan metode eksperimen dan analisis. Pembuatan minuman instan cokelat-kedelai ini mengacu pada minuman instan cokelat - jahe (Rosniati, 2011). Formulasi minuman instan dibuat dalam empat formula komposisi berat bahan yaitu formula 1 (gula sukrosa 55\%, kakao bubuk dari biji fermentasi 30\% dan krimer 15\%), formula 2 (gula sukrosa 55\%, kakao bubuk dari biji fermentasi 30\%, dan susu kedelai bubuk 15\%), formula 3 (gula sukrosa 55\%, kakao bubuk dari biji non fermentasi 30\% dan krimer 15\%) dan formula 4 (gula sukrosa 55\%, kakao bubuk dari biji non fermentasi 30\%, dan susu kedelai bubuk 15\%). Hasil penelitian menunjukkan bahwa formula yang terdiri dari sukrosa $55 \%$, kakao bubuk dari biji non fermentasi $30 \%$ dan susu kedelai bubuk $15 \%$ adalah formula terbaik dibandingkan dengan ketiga formula lainnya dengan nilai kandungan polifenol $11,25 \%$, lemak 8,35\%, gula total $45,89 \%$, asam amino esensial 4,17\%, asam amino non esensial 4,77\%, asam lemak tak jenuh 45,12\% dan asam lemak jenuh 26,42\%.
\end{abstract}

Kata Kunci : Minuman instan cokelat-kedelai, kakao bubuk, susu kedelai bubuk.

\section{PENDAHULUAN}

Kecenderungan perkembangan riset produk olahan pangan (makanan dan minuman) saat ini sangat dipengaruhi oleh semakin meningkatnya pemahaman dan kesadaran masyarakat tentang pentingnya hubungan kesehatan dan kebugaran. Sebagai salah satu komoditas perkebunan unggulan Indonesia, kakao sangat potesil untuk dikembangkan menjadi produk-produk olahan pangan yang mampu memenuhi tuntutan konsumen yang tidak sekedar menuntut nutrisi dan kelezatan tetapi juga adanya fungsi-fungsi lain yang bisa diperoleh dari kakao (Hariadi, 2013).

Berbagai data epidemiologi yang telah dipublikasikan mendukung adanya hubungan yang erat antara berbagai manfaat kesehatan dengan kandungan flvonoid pada kakao. Senyawa ini diketahui dapat memperbaiki aliran darah dan elastisitas pembuluh darah, menurunkan tekanan darah, sebagai antiinflamasi, menurunkan kolesterol, dan mencegah kanker (Corti et al, 2009). 
Telah banyak dilaporkan bahwa mengkonsumsi cokelat secara kontinu selama lebih dari tiga hari, dapat meningkatkan angka kualitas hidup terkait kesehatan (Health-Related Quality of Life) pada penderita kanker (Wong dan Lua, 2012). Mengkonsumsi 100 gram cokelat yang mengandung $500 \mathrm{mg}$ polifenol perhari dapat meningkatkan sensitivitas insulin dan menurunkan resistansi insulin, sekaligus menurunkan tekanan darah sistolik (Grassi, et al, 2005).

Demikian juga halnya dengan kedelai yang kaya akan isoflavon senyawa yang dapat melindungi tubuh melawan serangan penyakit kanker dan hati (Heinnermen, 2003) dan tidak mengandung kolesterol serta bebas laktosa (Liu, 1997) sehingga sinergitasnya dengan kakao untuk menghasilkan produkproduk olahan pangan akan meningkatkan fungsi-fungsi kesehatan.

Disisi lain, sejumlah hasil riset menunjukkan bahwa perlakuan fermentasi biji kakao yang dimaksudkan untuk mengembangkan citarasa cokelat olahan, dan perlakuan panas (pengeringan dan penyangraian) biji kakao dapat menyebabkan berkurangnya kadar flvonoid biji (Tomas Barbaran at al, 2007), sehingga perlakuanperlakuan tersebut perlu diminimalkan untuk mengoptimalkan fungsi-fungsi kesehatan dari kakao di dalam memproduksi produk pangan olahan.

Untuk memudahkan konsumsi produk olahan pangan khususnya dalam bentuk minuman instan, industri-industri pengolahan pangan umumnya menggunakan teknik pengeringan semprot (spraydrying).Namun alat pengering spry dryer harganya cukup mahal, oleh karena itu timbul alternatif lain untuk membuat produk minuman instan dengan peralatan sederhana, namun tehnik enkapsulasi tetap dapat dicapai yaitu dengan proses ko-kristalisasi.

Ko-kristalisasi merupakan salah satu teknik untuk pembuatan minuman instan dengan cara memasukkan komponen atau senyawa ke dalam dan diantara kristal sukrosa (Jackson and Lee, 1991).

Beberapa keistimewaan sukrosa sebagai dinding kapsul adalah dari segi harga relatif lebih murah, dapat larut dengan cepat, relatif stabil terhadap panas, tidak higroskopis dan memiliki masa simpan yang cukup lama pada suhu ruang (Chen, et al, 1991).

Penelitian ini bertujuan untuk menegmbangkan minuman instan cokelat kedelai sebagai minuman kesehatan dengan menggunakan kakao bubuk dari biji kakao fermentasi dan non fermentasi serta kedelai dalam bentuk susu kedelai bubuk.

\section{METODOLOGI}

\section{Bahan dan alat}

Bahan baku yang digunakan dalam penelitian ini adalah buah kakao diperoleh dari Kab. Bantaeng diolah menjadi kakao bubuk. Sedangkan bahan bantu adalah kedelai lokal diolah menjadi susu kedelai bubuk, sukrosa dan krimer (non dairy creamer).

Alat-alat yang digunakan selama penelitian adalah kotak fermentasi, parapara penjemuran, alat penyangrai (Roaster), alat pengupas biji kakao (desheller), alat pemasta, alat pengepress lemak kakao dan spry drayer.

\section{Metode Penelitian}

Penelitian ini dilakukan dalam 2 (dua) tahap yaitu tahap pertama adalah Penyiapan biji kakao fermentasi dan non fermentasi, penyiapan kakao bubuk, dan penyiapan susu kedelai bubuk, sedangkan tahap kedua adalah pembuatan minuman instan cokelat-kedelai.

\section{Penelitian Tahap Pertama}

\section{Penyiapan biji kakao fermentasi dan non fermentasi}

Penyiapan biji kakao dari biji basah menggunakan prosedur standar (Sri Mulato et al.2005), kecuali biji kakao yang digunakan adalah biji kakao non- fermentasi. Pengeringan biji kakao dilakukan dengan penjemuran terlindung untuk menjaga biji kakao yang sedang dikeringkan tidak terkena matahari langsung, khususnya pada saat terik, sampai diperoleh kadar air biji 6-7 \%. 
Penyiapan kakao bubuk

Biji kakao kering hasil fermentasi disangrai terlebih dahulu pada suhu $100^{\circ}$ C selama 40 menit sedangkan biji kakao kering non fermentasi tidak disangrai. Selanjutnya ke dua jenis biji masing-masing dikeluarkan kulit ari menggunakan desheller kemudian masing-masing digiling dengan menggunakan universal counching machine kapasitas $25 \mathrm{~kg}$, sehingga diperoleh pasta kakao.Selanjutnya pasta kakao dipress untuk memisahkan lemak kakao dan bungkil kakao. Bungkil kakao yang diperoleh digiling dengan menggunakan mesin pembubuk, kemudian diayak menggunakan ayakan ukuran mesh 200, sehingga dihasilkan kakao bubuk fermentasi dan non fermentasi.

\section{Penyiapan susu kedelai bubuk.}

Biji kedelai utuh direndam di dalam air dengan perbandingan kedelai : air $=1: 3 \mathrm{(b} / \mathrm{v})$ selama satu malam untuk melunakkan dan mengurangi rasa langu biji dan memudahkan pelepasan kulit ari. Biji kemudian dicuci dan dilepaskan kulit arinya, kemudian direbus selama 30 menit untuk melunakkan biji dan menon-aktifkan kegiatan enzim lipoksigenase. Biji kemudian digiling dengan mesin penggiling atau blender dengan menambahkan air panas dengan perbandingan biji kedelai : air = 1:3 (b/v) untuk memperoleh bubur kedelai. Bubur kedelai kemudian disaring untuk mendapatkan ekstrak, yang selanjutnya diproses lagi menjadi susu kedelai bubuk dengan menggunakan mesin pengering semprot (spray dryer), pada suhu inlet $120^{\circ}$ $\mathrm{C}$ dan outlet $70^{\circ} \mathrm{C}$ (Pramitasari, 2010).

\section{Penelitian Tahap Kedua}

\section{Pembuatan minuman instan cokelat- kedelai}

Minuman instan cokelat - kedelai dibuat dengan teknik ko-kristslisasi dengan menggunakan alat ko-kristalisasi. Formulasi produk dibuat dalam 4 (empat) formula. Komposisi bahan penyusun berdasarkan berat masing-masing bahan adalah seperti pada Tabel 1. Perbandingan gula sukrosa dan kakao bubuk ini mengacu pada formula pembuatan minuman instan cokelat - jahe dari penelitian Rosniati (2011).

Gula sukrosa ditambah dengan air bersih sebanyak $0,5 \%$ dari berat gula sukrosa, lalu dimasukkan kedalam wadah ko-kristalisasi kemudian dipanaskan pada suhu $100^{\circ} \mathrm{C}$. Sambil terus diaduk, larutan gula dibiarkan mendidih sampai larutan menjadi jenuh. Setelah larutan gula menjadi jenuh, suhu pemanasan diturunkan ke suhu sekitar $60^{\circ} \mathrm{C}$, kemudian ditambahkan kakao bubuk dan krimer (non - dairy creamer) atau susu kedelai bubuk sesuai dengan perlakuan sampai adonan berubah ke bentuk butiran kristal dengan kadar air sekitar $2 \%$. Selanjutnya butiran - butiran kristal dianginanginkan kemudian digiling menggunakan mesin giling atau blender untuk selanjutnya diayak dengan menggunakan ayakan mesh 60.

\section{Tabel 1.Formula pembuatan minuman instan cokelat-kedelai}

\begin{tabular}{|c|c|c|c|c|}
\hline \multirow[b]{2}{*}{ Komposisi } & \multicolumn{3}{|c|}{ Perlakuan Formula } & \multirow[b]{2}{*}{$\mathrm{F}_{4}(\%)$} \\
\hline & $\mathrm{F}_{1}(\%)$ & $\mathrm{F}_{2}(\%)$ & $\mathrm{F}_{3}(\%)$ & \\
\hline $\begin{array}{l}\text { Sukrosa } \\
\text { Kakao } \\
\text { bubuk dari }\end{array}$ & 55 & 55 & 55 & 55 \\
\hline $\begin{array}{l}\text { biji } \\
\text { fermentasi }\end{array}$ & 30 & 30 & - & - \\
\hline $\begin{array}{l}\text { Kakao bubuk } \\
\text { dari biji non } \\
\text { fermentasi }\end{array}$ & - & - & 30 & 30 \\
\hline $\begin{array}{l}\text { susu } \\
\text { kedelai } \\
\text { bubuk }\end{array}$ & - & 15 & - & 15 \\
\hline Krimer & 15 & - & 15 & - \\
\hline
\end{tabular}

\section{Metode Analisis}

Analisis bahan baku (kakao bubuk) dilakukan terhadap $\mathrm{pH}$ menggunakan $\mathrm{pH}$ meter digital, kadar air dengan metode pemanasan dalam oven pada suhu $105^{\circ} \mathrm{C}$, protein dengan metode kjeldhal (AOAC, 1996), total polifenol dengan menggunakan HPLC, dan lemak dengan metode soxhlet (AOAC, 1996)

Sedangkan analisis produk dilakukan terhadap total polifenol dengan HPLC, asam amino dengan metode Asama amino 
analyser, asam lemak dengan HPLC, lemak dengan metode soxhlet (AOAC, 1996) dan kadar gula total dengan metode Luff Schoorl.

\section{Analisis data}

Data hasil uji laboratorium diolah secara deskripsi.

\section{HASIL DAN PEMBAHASAN}

\section{Bahan Baku}

Hasil analisis bahan baku kakao bubuk dari biji fermentasi dan non fermentasi dapat dilihat pada Tabel 2.

Tabel 2. Hasil analisis kakao bubuk dari biji fermentasi dan non fermentasi

\begin{tabular}{lcc}
\hline Karakteristik & $\begin{array}{c}\text { Kakao bubuk } \\
\text { dari biji } \\
\text { fermentasi } \\
(\%)\end{array}$ & $\begin{array}{c}\text { Kakao bubuk } \\
\text { dari biji non } \\
\text { fermentasi } \\
(\%)\end{array}$ \\
\hline Kadar air & 5.00 & 5,00 \\
pH & 4.97 & 6.68 \\
Protein & 14.50 & 15.39 \\
Lemak & 18.37 & 12.03 \\
Polifenol & 13.95 & 14.03 \\
\hline
\end{tabular}

Dari Tabel 2 terlihat bahwa kadar air kakao bubuk baik dari bji fermentasi maupun dari non fermentasi mempunyai kadar air masing - masing $5.00 \%$ memenuhi persyaratan SNI kakao bubuk 01 - 37471995 yaitu maksimum 5,00 \%.

Pada Tabel 2, terlihat bahwa pH kakao bubuk dari biji fermentasi lebih rendah dari pada biji non fermentasi. Hal ini disebabkan karena pada saat berlangsungnya proses fermentasi terjadi akumulasi asam asetat ke dalam keping biji dan kulit ari. Dengan demikian akan terjadi reaksi enzimatis di dalam keping dan akan timbul aroma asam serta turunnya nilai $\mathrm{pH}$ keeping biji.

Pada Tabel 2 juga terlihat bahwa kandungan polifenol kakao bubuk dari biji non fermentasi lebih tinggi dari pada biji fermentasi. Hal ini disebabkan karena selama fermentasi biji kakao terjadi penguraian senyawa polifenol menjadi senyawa pembentuk calon citarasa dan senyawa pembentuk warna coklat sehingga kandungan polifenol dalam biji mengalami penurunan.

Menurut Misnawi et al (2004), polifenol dalam biji kakao tanpa fermentasi terdiri dari tiga kelompok utama yaitu flavan-3-olsatau katekin, anthocyanin, dan proanthocyanidins, dengan kandungan polifenol rata-rata dari $120-180 \mathrm{~g} / \mathrm{kg}$.

Dari Tabel 2 terlihat bahwa kadar lemak kakao bubuk dari biji fermentasi lebih tinggi dari pada non fermentasi, sedangkan kadar protein terjadi sebaliknya. Hal ini disebabkan karena pada proses fermentasi terjadi penurunan kandungan bahan bukan lemak seperti protein, polifenol dan karbohidrat yang terurai, sehingga secara relatif kadar lemak akan meningkat (De Brito et al., 2000; Camu et al., 2008).

\section{Produk Minuman Instan Cokelat-Kedelai}

Hasil analisis polifenol, kadar lemak dan kadar gula total produk minuman instan cokelat-kedelai dapat dilihat pada Tabel 3.

Tabel 3. Hasil analisis polifenol, kadar

lemak dan kadar gula total minuman instan cokelat-kedelai.

\begin{tabular}{cccc}
\hline $\begin{array}{c}\text { Perlakuan } \\
\text { Formula }\end{array}$ & $\begin{array}{c}\text { Kadar } \\
\text { Polifenol } \\
(\%)\end{array}$ & $\begin{array}{c}\text { Kadar } \\
\text { Lemak } \\
(\%)\end{array}$ & $\begin{array}{c}\text { Kadar } \\
\text { Gula (\%) }\end{array}$ \\
\hline $\mathrm{F}_{1}$ & 7.66 & 12.56 & 50.13 \\
$\mathrm{~F}_{2}$ & 7.91 & 11.36 & 51.15 \\
$\mathrm{~F}_{3}$ & 10.42 & 10.97 & 47.22 \\
$\mathrm{~F}_{4}$ & 11.25 & 8.35 & 45.89 \\
\hline
\end{tabular}

Polifenol

Pada Tabel 3 terlihat bahwa produk minuman instan cokelat - kedelai dengan $\mathrm{F}_{3}$ (penambahan kakao bubuk dari biji non fermentasi dan krimer) dan $\mathrm{F}_{4}$ (penambahan kakao bubuk dari biji non fermentasi dan susu kedelai bubuk) mempunyai kadar polifenol lebih tinggi dari pada $F_{1}$ (penambahan kakao bubuk dari biji fermentasi dan Krimer) dan $F_{2}$ (penambahan kakao bubuk dari biji fermentasi dan susu kedelai bubuk). Tingginya kadar polifenol produk $\mathrm{F}_{3}$ dan $\mathrm{F}_{4}$ disebabkan karena adanya penambahan kakao bubuk dari biji non fermentasi yang mempunyai kadar polifenol yang lebih tinggi dari pada kakao bubuk dari biji fermentasi, 
hal ini didukung dari hasil analisis bahan baku kakao bubuk seperti yang tertera pada Tabel 2. Seperti dijelaskan sebelumnya bahwa selama fermentasi biji kakao terjadi penguraian senyawa polifenol menjadi senyawa pembentuk calon citarasa dan senyawa pembentuk warna coklat sehingga kandungan polifenol dalam biji mengalami penurunan.

Kandungan polifenol pada biji kakao yang tidak difermentasi nyata lebih tinggi dibandingkan dengan yang difermentasi, karena pada proses fermentasi kandungan polifenol banyak berkurang melalui proses oksidasi, polimerisasi, dan pengikatan oleh protein (Nazaruddin et al., 2006 dan Prayoga et al., 2013). Selama proses fermentasi, senyawa polifenol menyebar keluar dari sel penyimpanannya dan kemudian mengalami oksidasi membentuk senyawa bermolekul tinggi (Bernaert et al., 2012).

Senyawa flavonoid termasuk dalam sub kelompok senyawa polifenol (De Noon, 2003), yang berfungsi sebagai antioksidan alami dapat mengurangi sejumlah gugus radikal bebas dalam tubuh manusia dan dapat menyediakan pertahanan terhadap serangan spesies oksigen yang reaktif atau Reaktif Oksigen Species / ROS (Vicioli, et al, 2000).

Dari Tabel 3 juga menunjukkan bahwa produk minuman instan cokelatkedelai $F_{2}$ (penambahan kakao bubuk dari biji fermentasi dan susu kedelai bubuk) mempunyai kadar polifenol lebih tinggai dibanding dengan $F_{1}$ (penambahan kakao bubuk dari biji fermentasi dan krimer), demikian pula produk $\mathrm{F}_{4}$ (penambahan kakao bubuk dari biji non fermentasi dan susu kedelai bubuk) mempunyai kadar polifenol lebih tinggi dibanding $\mathrm{F}_{3}$ (penambahan kakao bubuk dari biji non fermentasi dan krimmer). Hal ini disebabkan karena pada produk $F_{2}$ danF $_{4}$ mendapat penambahan susu kedelai bubuk masing-masing sebanyak $15 \%$. Diketahui bahwa kedelai merupakan sumber isoflavon dan termasuk subkelas dari flavonoid, yakni kelompok besar antioksidan polifenol. Polifenol adalah senyawa yang terdiri dari 2 gugus yaitu flavanoid dan turunan asam sinamat. Menurut (Baratawidjaja,
2000; dan Afriansyah, 2004) bahwa salah satu jenis flavonoid yang sangat banyak terdapat pada biji kedelai adalah isoflavon yang dapat berfungsi untuk meningkatkan sistem imunitas, disamping itu kandungan senyawa flavonoid dan isoflavonoid dalam susu kedelai berpotensi sebagai antitumor/ antikanker, anti virus dan anti alergi.

Dari Tabel 3 terlihat bahwa kandungan polifenol produk minuman instan cokelat kedelai dari semua perlakuan yang tertinggi adalah produk $\mathrm{F}_{4}$ (penambahan kakao bubuk dari biji non fermentasi dan susu kedelai bubuk).

\section{Lemak}

Dari Tabel 3 terlihat bahwa produk minuman instan cokelat-kedelai dengan perlakuan $F_{1}$ (penambahan kakao bubuk dari biji fermentasi dan krimer) dan $F_{2}$ (penambahan kakao bubuk dari bijifermentasi dan susu kedelai bubuk) mempunyai kadar lemak lebih tinggi dari pada produk $\mathrm{F}_{3}$ (penambahan kakao bubuk dari biji non fermentasi dan krimer) dan $\mathrm{F}_{4}$ (penambahan kakao bubuk dari biji non fermentasi dan susu kedelai bubuk). Tingginya kadar lemak pada produk $F_{1}$ dan $F_{2}$ disebabkan karena adanya penambahan kakao bubuk dari biji fermentasi masing-masing sebanyak $30 \%$.

Berdasarka hasil analisis bahan baku kakao bubuk (Tabel 1) ternyata kakao bubuk yang diolah dari biji fermentasi mengandung lemak yang lebih tinggi dari pada yang diolah dari biji non fermentasi.

Dari Tabel 3 juga menunjukkan bahwa kadar lemak produk $F_{1}$ (penambhan kakao bubuk dari biji fermentasi dan krimer) lebih tinggi dibanding produk $F_{2}$ (penambahan kakao bubuk dari biji fermentasi dan susu kedelai bubuk), demikian halnya dengan produk $\mathrm{F}_{3}$ (penambahan kakao bubuk dari biji non fermentasi dan krimer) lebih tinggi dari pada $\mathrm{F}_{4}$ (penambahan kakao bubuk dari biji non fermentasi dan susu kedelai bubuk). Tingginya kadar lemak pada produk $\mathrm{F}_{1}$ dan $\mathrm{F}_{3}$ karena adanya penambahan krimer masingmasing sebanyak $15 \%$.

Krimer (non-dairy creamer) adalah produk pengganti susu atau krim yang merupakan produk emulsi lemak dalam air, 
dibuat dari minyak nabati yang dihidrogenasi dengan penambahan bahan tambahan pangan yang diizinkan (Anonim, 2012a). Non Dairy Creamer terbuat dari minyak kelapa murni dan / atau hydrogenated coconut oil serta minyak kelapa sawit dengan spesifikasi kadar lemak minimum 32\% (Kana Krimer).

Konsumsi lemak yang berlebih akan menyebabkan peningkatan kadar kolesterol darah (Arisman, 2004). Berdasarkan penelitian Tuminah (2009), menyebutkan bahwa pola makan seperti konsumsi makanan yang tinggi lemak total atau lemak jenuh, kolesterol, serta kurangnya konsumsi karbohidrat merupakan faktor yang mempengaruhi kadar HDL dan merupakan faktor risiko penyakit jantung coroner (PJK). Menurut Yusuf et al (2013), bahwa konsumsi lemak terutama asam lemak jenuh, akan berpengaruh terhadap kadar Low Density Lipoprotein (LDL) yang menyebabkan darah mudah menggumpal, selain itu asam lemak jenuh mampu merusak dinding pembuluh darah arteri sehingga menyebabkan penyempitan. Studi epidemiologi yang dilakukan Hardinsyah (2011), membuktikan bahwa terdapat hubungan positif yang bermakna antara konsumsi lemak (asam lemak jenuh) menyebabkan hiperkolesterol yang merupakan faktor risiko dari PJK.

Pada Tabel 3 terlihat bahwa dari semua produk minuman instan cokelat - kedelai ternyata produk $\mathrm{F}_{4}$ (penambahan kakao bubuk dari biji non fermentasi dan susu kedelai bubuk) mempunyai kadar lemak yang paling rendah. Hal ini tentu sangat menguntungkan minuman instan cokelat kedelai dengan polifenol tinggi tetapi rendah kandungan lemak sebagai produk minuman kesehatan.

\section{Kadar Gula Total}

Dari Tabel 3 terlihat bahwa produk $F_{1}$ (penambahan kakao bubuk dari biji fermentasi dan krimer) dan $\mathrm{F}_{2}$ (penambahan kakao bubuk dari biji fermentasi dan susu kedelai bubuk) mempunyai kadar gula total lebih tinggi dari pada produk $\mathrm{F}_{3}$ (penambahan kakao bubuk dari biji non fermentasi dan krimer) dan $F_{4}$ (penambahan kakao bubuk dari biji non fermentasi dan susu kedelai bubuk). Meskipun penambahan gula sukrosa ke dalam adonan dalam jumlah yang sama untuk semua perlakuan, tetapi produk yang dihasilkan mempunyai kadar gula total yang berbeda. Hal ini dipengaruhi oleh adanya penambahan jenis kakao bubuk yang berbeda. Produk $F_{1}$ dan $F_{2}$ mendapat penambahan kakao bubuk dari biji fermentasi masing-masing $30 \%$, sedangkan produk $F_{3}$ dan $\mathrm{F}_{4}$ mendapat penambahan kakao bubuk dari biji non fermentasi masing-masing $30 \%$.

Selama fermentasi, di dalam biji kakao akan terjadi penguraian senyawa polifenol, protein, dan gula oleh adanya enzim yang akan menghasilkan senyawa calon aroma, perbaikan citarasa, dan perubahan warna. Selama fermentasi kadar polifenol mengalami penurunan, karena terjadinya difusi senyawa polifenol keluar dari keping biji, sedangkan antosianin yangmerupakan salah satu senyawa pembentuk polifenol terhidrolisa oleh enzim menjadi gula dan sianidin. Menurut Desyana, 2006; Lopiies dan Yumas 2008, menyatakan bahwa biji kakao yang telah difermentasi mengalami peningkatan kadar gula pereduksi (glukosa dan fruktosa).

Dari Tabel 3 terlihat bahwa semua produk minuman instan cokelat-kedelai ternyata produk $\mathrm{F}_{4}$ (penambahan kakao bubuk dari biji non fermentasi dan susu kedelai bubuk) mempunyai kadar gula yang paling rendah, hal ini tentunya menguntungkan sebagai minuman kesehatan, terutama bagi orang yang diet kalori dan penderita obesitas.

Hasil analisis asam amino dan asam lemak produk minuman instan cokelat-kedelai dapat dilihat pada Tabel 4 dan Tabel 5 .

Tabel 4. Hasil analisis asam amino produk minuman instan cokelat-kedelai.

\begin{tabular}{lllll}
\hline $\begin{array}{l}\text { Asam Amino } \\
\text { Esensial }\end{array}$ & $\begin{array}{l}\text { F1 } \\
\text { (\% } \\
\text { w/w) }\end{array}$ & $\begin{array}{l}\text { F2 } \\
\text { (\%/w) }\end{array}$ & $\begin{array}{l}\text { F3 } \\
\mathbf{( \% / w )}\end{array}$ & $\begin{array}{l}\text { F4 } \\
\text { (\% } \\
\text { w/w })\end{array}$ \\
\hline Methionine & 0.09 & 0.12 & 0.09 & 0.12 \\
Phenylalanine & 0.36 & 0.53 & 0.39 & 0.49 \\
Leucine & 0.46 & 0.74 & 0.48 & 0.65 \\
Threonine & 0.28 & 0.46 & 0.29 & 0.44 \\
Lysine & 0.42 & 0.76 & 0.41 & 0.52
\end{tabular}




\begin{tabular}{lcccc} 
Arginine & 0.45 & 0.77 & 0.47 & 0.76 \\
I-Leucine & 0.30 & 0.44 & 0.28 & 0.42 \\
Histidine & 0.13 & 0.26 & 0.14 & 0.22 \\
Valine & 0.42 & 0.60 & 0.43 & 0.55 \\
Total & 2.91 & 4.68 & 2.98 & 4.17 \\
$\begin{array}{l}\text { A.A.Esensial } \\
\text { A.A. Non }\end{array}$ & & & & \\
Esensial & & & & \\
Aspartic acid & 0.66 & 1.12 & 0.68 & 1.09 \\
Glutamic acid & 1.19 & 1.95 & 1.21 & 1.93 \\
Serine & 0.33 & 0.50 & 0.33 & 0.47 \\
Glysine & 0.29 & 0.50 & 0.31 & 0.47 \\
Alanine & 0.29 & 0.50 & 0.31 & 0.47 \\
Tyrosine & 0.29 & 0.41 & 0.30 & 0.4 \\
Total Asam & 3.05 & 4.53 & 3.11 & 4.77 \\
Amino Non & & & & \\
Esensial & & & & \\
\hline
\end{tabular}

\section{Asam Amino}

Pada Tabel 4 terlihat bahwa produk minuman instan cokelat-kedelai mengandung asam amino esensial dan asam amino non esensial. Produk $F_{2}$ (penambahan kakao bubuk dari biji fermentasi dan susu kedelai bubuk) dan $\mathrm{F}_{4}$ (penambahan kakao bubuk dari biji non fermentasi dan susu kedelai bubuk) mempunyai kadar asam amino esensial dan non esensial yang lebih tinggi dari pada produk $F_{1}$ (penambhan kakao bubuk dari biji fermentasi dan krimer) dan $\mathrm{F}_{3}$ (penambahan kakao bubuk dari biji non fermentasi dan krimer). Hal ini disebabkan karena produk $F_{2}$ dan $\mathrm{F}_{4}$ mendapat penambahan susu kedelai bubuk masing - masing sebanyak $15 \%$.

Kedelai telah dikenal mengandung protein yang cukup tinggi.Protein kedelai mempunyai kandungan asam amino esensial yang paling tinggi dibandingkan kacangkacangan lain dan mutunya mendekati protein susu (Koswara, 2004).

Sebagaimana diketahui bahwa asam amino esensial adalah asam amino yang sangat diperlukan oleh tubuh, tetapi tidak dapat disintesis dari bahan makanan dengan kecepatan yang memadai (sesuai dengan kebutuhan), oleh karena itu harus disediakan dalam bentuk jadi (sudah ada dalam bahan makanan yang dikonsumsi). Asam amino non esensial juga sangat diperlukan oleh tubuh sama pentingnya seperti asam amino esensial. Akan tetapi asam amino non esensial ini dapat disintesis oleh tubuh dalam jumlah yang memadai dari bahan-bahan yang ada dalam makanan.

Salah satu parameter mutu makanan adalah kandungan asam amino esensial pada makanan tersebut. Semakin tinggi jumlah asam amino esensial yang terkandung maka mutu makanan tersebut semakin baik. \begin{tabular}{llr}
\multicolumn{1}{c}{ Manfaat } & asam amino terhadap \\
kesehatan & adalah: & menghambat \\
pertumbuhan & tumor dan kanker,
\end{tabular} pertumbuhan tumor dan kanker,
meningkatkan detoksifikasi amonia, merangsang produksi hormon pertumbuhan, memperkuat tulang serta kolagen, menjaga kesehatan jantung, membantu menghindari depresi, dan meningkatkan daya ingat (Anonim, 2013).

Hasil analisis asam lemak produk minuman cokelat-kedelai dapat dilihat pada Tabel 5.

\section{Tabel 5.Kadar asam lemak produk minuman instan cokelat-kedelai}

\begin{tabular}{|c|c|c|c|c|}
\hline $\begin{array}{c}\text { Asam Lemak } \\
\text { Jenuh }\end{array}$ & $\begin{array}{l}\text { F } 1 \\
(\% \\
w / w)\end{array}$ & $\begin{array}{l}\text { F } 2 \\
(\% \\
w / w)\end{array}$ & $\begin{array}{l}F 3 \\
(\% \\
w / w)\end{array}$ & $\begin{array}{c}F 4 \\
(\% \\
w / w)\end{array}$ \\
\hline Caprilic acid & 2.07 & - & 2.51 & - \\
\hline Capric acid & 1.79 & - & 2,09 & - \\
\hline Lauric acid & 17.38 & 0.02 & 19.27 & - \\
\hline Myristic acid & 5.90 & 0.06 & 6.47 & 0.05 \\
\hline $\begin{array}{l}\text { Pentadecanoic } \\
\text { acid }\end{array}$ & 0.02 & 0.02 & - & - \\
\hline Palmitic acid & 14.46 & 14.97 & 12.25 & 12.79 \\
\hline $\begin{array}{l}\text { Heptadecanoic } \\
\text { acid }\end{array}$ & 0.10 & 0.12 & 0.08 & 0.09 \\
\hline Stearic acid & 18.90 & 16.47 & 16.89 & 13.49 \\
\hline Arach & 0.37 & 0.44 & - & - \\
\hline Behenic acid & 0.09 & 0.18 & - & - \\
\hline $\begin{array}{l}\text { Total A.Lemak } \\
\text { Jenuh }\end{array}$ & 61.08 & 32.28 & 59.57 & 26.42 \\
\hline \multicolumn{5}{|l|}{$\begin{array}{l}\text { A. Lemak Tak } \\
\text { Jenuh }\end{array}$} \\
\hline Palmitoleic acid & 0.09 & 0.10 & 0.06 & 0.09 \\
\hline Elaidic & 0.37 & 0.03 & 0.02 & 0.05 \\
\hline Linoleic acid & 1.77 & 25.20 & 0.94 & 19.10 \\
\hline $\begin{array}{l}\text { Cis-11- } \\
\text { Eicocenoic acid }\end{array}$ & 0.08 & 2.70 & 0.07 & 1.84 \\
\hline $\begin{array}{l}\text { Cis-11- } \\
\text { Eicicedienoic } \\
\text { acid }\end{array}$ & 0.03 & 0.04 & - & 0.04 \\
\hline
\end{tabular}




$\begin{array}{lcccc}\text { Oleic acid } & - & 25.42 & 11.31 & 24.00 \\ \text { Total A. Lemak } & 2.34 & 53.40 & 1.20 & 45.12 \\ \text { Tak Jenuh } & & & & \end{array}$

\section{Asam Lemak}

Pada Tabel 5 terlihat bahwa produk minuman instan cokelat-kedelai mengandung asam lemakjenuh dan asam lemak takjenuh. Produk $F_{1}$ (penambahan kakao bubuk dari biji fermentasi dan krimer) dan $F_{3}$ (penambahan kakao bubuk dari biji non fermentasi dan krimer) mempunyai kadar asam lemak jenuh yang jauh lebih tinggi, sedangkan asam lemak tak jenuhnya sangat rendah. Hal ini disebabkan karena produk F1 dan F3 mendapat penambahan krimer masingmasing sebanyak $15 \%$. Seperti dijelaskan sebelumnya bahwa krimer terbuat dari minyak kelapa murni dan / atau hydrogenated coconut oil serta minyak kelapa sawit dengan spesifikasi kadar lemak minimum $32 \%$. Sebaliknya produk $F_{2}$ (penambahan kakao bubuk dari biji fermentasi dan susu kedelai bubuk) dan $\mathrm{F}_{4}$ (penambahan kakao bubuk dari biji non fermentasi dan susu kedelai bubuk) mengandung asam lemak jenuh yang rendah tetapi asam lemak tak jenuhnya tinggi. Hal ini disebabkan karena adanya penambahan susu kedelai bubuk masing-masing sebanyak $15 \%$.

Kedelai mengandung $85 \%$ asam lemak tak jenuh terutama asam linoleat dan asam oleat, sedangkan sisanya $15 \%$ berupa asam lemak jenuh terdiri dari asam palmitat (Koswara, 1992). Asam lemak tak jenuh ini dapat mencegah timbulnya pengerasan pembuluh-pembuluh nadi (arterio sclerosis), membantu menurunkan kadar kolesterol jahat (LDL) dan dapat mengurangi resiko penyakit jantung. Selain itu, kedelai juga kaya akan asam linoleat, asam linolenat, dan lesitin. Linoleat dan linolenat adalah asam lemak esensial dari kelompok omega- 6 dan omega-3, yang dapat mengurangi resiko penyakit jantung dan diabetes (Anonim, 2008).

\section{SIMPULAN}

Minuman instan cokelat-kedelai pada penelitian ini diformulasi dari kakao bubuk yang diolah dari biji kakao fermentasi dan non fermentasi, sukrosa, instan susu kedelai bubuk dan atau krimerDari ke empat formula minuman instan cokelat-kedelai yang diteliti ternyata formula yang terdiri dari sukrosa 55 $\%$, kakao bubuk dari biji non fermentasi $30 \%$ dan instan susu kedelai bubuk $15 \%$ adalah produk yang terbaik dengan nilai kandungan polifenol $11,25 \%$, lemak $8,35 \%$, gula total $45,89 \%$, asam amino esensial $4,17 \%$, asam amino non esensial $4,77 \%$, asam lemak tak jenuh 45,12 \% dan asam lemak jenuh 26,42 $\%$.

\section{DAFTAR PUSTAKA}

1. Anonim. 2008 .Kandungan Gizi Sebagai manfaat Susu Kedelai. http://susukedelainatoya.blogspot. com/2008/11/kandungan-gizi-sbgmanfaat-susu-kedelai.html. Diakses tgl 4-9-2009.

2. Anonim, 2012a. Pangan dan Zat Gizi. http://zaifbio.wordpress.com/2012/06/ 29/pangan-dan-zat-gizi/

3. Anonim. 2012b. Palm Based Non-dairy Creamer. In Palm Oil/ Palm Kernel Oil. Application.http://www.americanpalmoil. com/publications/creamer.pdf. diakses tgl 27 November 2012.

4. Anonim, (2013). Apa Manfaat Asam Amino? Makanan Yang Mengandung Asam Amino. http://amazine.co/18021/apamanfaat-asam amino - mkanan - yang mengandung-asam-amino/

5. Afriansyah N. 2004. Tempe Dapat Hambat Kanker Prostat. http://www. kompas.com. Diakses tgl 8 mei 2004.

6. AOAC. (1996). Official methods of analysis of the association of official analytical chemist. Association of official analytical chemist Washington, D.C.

7. Arisman. 2004. Gazi Dalam Daur Kehidupan. Jakarta : EGC

8. Baratawidjaja, K.G, 2000, Imunologi Dasar. Edisi IV, Balai Penerbit Fakultas Kedokteran Universitas Indonesia, Jakarta, 3-246.

9. Bernaert, H., Blondeel, L., Allegaert, L., \& Lohmueller, T. 2012. Industrial treatment of cocoa in chocolate production: health 
implication. Dalam : Paoletti et al. (eds). Chocolate and Health. Springer-Verlag, Italia, 17-31. ISBN: 978-88-470-2037-5. DOI: 10.1007/978-88-470-2038-2.

10. Camu, N.; T.D. Winter; S.K. Addo; J.S. Takrama; H. Bernart \& L.D. Vuyst. 2008. Fermentation of cocoa beans: Influence of microbial activities and polyphenol concentrations on the flavour of chocol at e. Journal of the Science of Food and Agriculture, 88, 2288-2297.

11. Chen, $A E ;$ Viega, MF dan Rizutto, $A B$, 1991. Cocristallization, An Encapsulation Process, Food Tech, 24 : 289 - 297.

12. Corti, R; A.J, flamer, N.K, Hollenberg dan T.F, Lusher, 2009. Cocoa and Cardiovasculer Health, Circulation 119 : $1433-1441$

13. De Brito, E.S.; N.H.P. Garcia; M.I. Gallao; A.L. Cortelazzo; P.S. Fevereiro \& M.R. Braga 2000. Structural and chemical changes in cocoa (Theobroma cacao L.) during fermentation, drying and roasting. Journal of the Science of Food and Agriculture, 81, 281-288.

14. De Noon, D. 2003. "Dark chocolate is healthy chocolate". Web MD Medical News, August 27. Http :// www. claveland Clinic.org./heart - ceterpub/ guide/prevention/nutrition. Diakses 27 Agustus 2009.

15. Desyana, S .2006. Pengaruh Aktivator Pada Proses Fermentasi Terhadap Kualitas Biji Kakao.Tugas Akhir, Jurusan Teknik Kimia. Politeknik Negeri Ujung Pandang.

16. Grassi, D. C. Lippi, S. Necozione, G. Desideri, and C. Ferri. 2005. Shortterm administration of dark chocolate is followed by a significant increase ininsulin sensitivity and a decrease in blood pressure in healthy persons American Journal of Clinical Nutrition. (81) : 611-614.

17. Hardinsyah. 2011. Analisis Konsumsi Lemak, Gula dan Garam Penduduk Indonesia. Gizi Indon 2011, 34(2):92-100

18. Hariyadi, P. 2013. Tren Perkembangan Riset Produk Olahan Kakao. Prsiding Seminar nasional Industri Kakao Dan
Hasil Perkebunan Lainnya. Balai Besar Industri Hasil Perkebunan, Makassar.

19. Heinnermen, J.2003.Khasiat Kedelai Bagi Kesehatan Anda. Penerbit Prestasi Pustakaraya, Jakarta, Indonesia.

20. Informasitips, 2010. Trigliserida (Lemak) dan Kaitannya dengan Kolesterol. informasitips.com , Info Sehat. Diakses 20 Juli 2010.

21. Jackson and K.Lee., 1991, Microenkapsulation and Food Industry, Leberson Wiss-U Techn.

22. Jinap, S. \& P.S. Dimick, 1991. Effect of roasting on acidic characteristics of cocoa beans. Journal of the Science of Food Agriculture, 54, 317-321.

23. Kana Krimer, -----non dairy creamer http://kanakrimer.indonetwork.co.id/ group\%2B144228/non-dairy-creamerkrimer. Diakses tgl 12 Mei 2016

24. Koswara, S. 1992. Teknologi Pengolahan Kedelai. PT. Penebar Swadaya.

25. Koswara S. 2004. Susu Kedelai Tak Kalah Dengan Susu Sapi. http://www. indomedia.com. Diakses tgl 8mei 2004.

26. Liu K. S. 1997. Soybeans: Chemistry, technology, and utilization. New York, Chapman \& Hall.

27. Loppies J.E dan M. Yumas. 2008. Mempelajari Proses Fermnetasi Biji Kakao Dengan Penambahan Aktivator, JIHP, Vol 3 (1). Balai Besar Industri Hasil Perkebunan.

28. Misnawi, B. Jamilah, dan S. Nazamid. 2004. "Effect of polyphenol concentration on pyrazine formation during cocoa liquor rroasting," Food Chemistry, vol. 85 (1), pp. 73-80.

29. Nazaruddin, R., Seng, L. K., Hassan, O. \& Said, M. 2006. Effect of pulp preconditioning on the content of polyphenols in cocoa beans (Theobroma cacao L.) during fermentation. Indust. Crops Prod. 24, 87-94.

30. Pramitasari, D, 2010. Penambahan ekstrakjahe (Zingiber officinale rose) alam pembuatan susu kedelai bubuk instan dengan metode spray drying: Komposisi kimia, sifat sensori dan aktifitas anioksidan. Skripsi, Program Studi Teknologi Hasil Pertanian, Fakultas 
Pertanian, Universitas Sebelas Maret, Surakarta.

31. Prayoga, R.D., Murwani, R., \& Anwar, S. 2013. Polyphenolaxtracts from low quality cocoa beans: antioxidant, antibacterial and food colouring properties. Internat. Food Res. J.20(6), 3275-3281.

32. Rosniati. 2011. Pengaruh Suhu Pemanasan Ekstrak Jahe dan Sukrosa Terhadap Karakteristik Instan JaheCokelat. J IHP Vol 6 (2).

33. Sri Mulato ; Widyotomo ; Misnawi dan Suharyanto, E. V ; 2005. Pengolahan Produk Primer dan Sekunder Kakao. Pusat Penelitian Kopi dan Kakao Indonesia, Jember

34. Tomas-Barberan F.,A., CienfuegosJovellanos, E., Marín, A., Muguerza, B., Gil-Izquierdo, A., Cerda, B., Zafrilla, P, Morillas, J., Mulero, J., Ibarra, A., Pasamar, M.,A., Ramón, D., Espín, J.,C.,2007. A New Process To Develop a Cocoa Powder with Higher Flavanoid Monomer Content and Enhanced Biovailability in Healthy Humans. Agricultural And Food Chemistry, 55, 3926-3935.
35. Tuminah, S. 2009. Efek Asam Lemak Jenuh Dan Asam Lemak Tak Jenuh "Trans" Terhadap Kesehatan. Media Penelitian Dan Pengembang Kesehatan volume XIX tahun 2009, suplemen II.

36. Vicioli, F; Borsami, L and Galili, C 2000. Diet and prevention of coronery heart disease :" the potential role of phytochemicals" Cardiovasc. Research 7 (3) : 419 -423.

37. Wong, S.Y, PL Lua. 2012. Effects of dark chocolate consumption on anxiety, depressive symptoms and health related quality of life status among cancer patients. HealthandEnvironmentJournal. (3): 27-35.

38. Yusuf, F., Sirajuddin, S., Najamuddin, U. 2013. Analisis Kadar AsamLemak Jenuh Dalam Gorengan Dan Minyak Bekas Hasil Penggorengan Makanan Jajanan Di Lingkungan Workshop Universitas Hasanuddin. Program Studi IImu Gizi Fakultas Kesehatan Masyarakat Universitas Hasanuddin. 